\title{
A "New" Thematic, Integrated Curriculum for Primary Schools of Trinidad and Tobago: A Paradigm Shift
}

\author{
Yvonne J.John ${ }^{1}$ \\ ${ }^{1}$ Centre for Education Programmes, The University of Trinidad and Tobago, South Valsayn, Trinidad and Tobago \\ Correspondence: Yvonne J. John, 50 Mora Drive, Homeland Gardens, Cunupia, Trinidad and Tobago. E-mail: \\ yvonnejulie.john@gmail.com
}

Received: July 20, 2015

Accepted: August 14, 2015

Online Published: August 17, 2015

doi:10.5430/ijhe.v4n3p172

URL: http://dx.doi.org/10.5430/ijhe.v4n3p172

\begin{abstract}
After February 2014, teachers in Trinidad and Tobago were required to implement a new, integrated curriculum. The major considerations of the new curriculum were literacy and numeracy skills taught across the curriculum, assessment of learning, differentiated instruction, and the integration of Information Communication Technology (ICT). This study examined the efficacy of the new primary school curriculum introduced by the Ministry of Education of Trinidad and Tobago (MOETT). It measured prospective teachers' abilities to implement the curriculum effectively to meet the needs of diverse students in the inclusive environment after systematic training. The study used a mixed-methods design aimed at triangulating a nonequivalent-group, posttest-only design with survey responses from the sample group of prospective teachers. Findings from the study revealed prospective teachers were more effective in meeting the needs of all students while implementing the new thematic, integrated curriculum when trained compared to the prospective teachers implementing the curriculum without training.
\end{abstract}

Keywords: Thematic, Integrated curriculum, Differentiation, Assessment, Primary schools

\section{Introduction}

The implementation of the new curriculum in primary schools of Trinidad and Tobago has changed the focus of practicum courses at the University of Trinidad and Tobago (UTT). MOETT employs most of the students reading for the Bachelor of Education degree, upon graduation, to teach in the 537 primary schools. Additionally, UTT is a provider of education services in Trinidad and Tobago. Thus, it is the responsibility of teacher educators at the Centre for Education Programmes, UTT, to ensure that prospective teachers know the contents of the new curriculum and be able to master the implementation.

According to the curriculum guide of the MOETT (2014), in the context of primary education in Trinidad and Tobago, an integrated thematic curriculum signifies a shift in teaching and learning. The shift occurs when students will not exclusively experience subjects as discrete and separated, but rather within themes, placed in context and logically organized and linked to real life situations. Although the integrated thematic curriculum is not a new concept, best practice advocates that people gain knowledge best when learning in the context of a coherent "whole," making connections to real-world situations. Thematic integrated instruction puts the teaching of cognitive skills (reading, mathematics, science, writing, social studies and other subjects identified) in the context of a real-world subject that is both specific enough to be practical, and broad enough to allow creative exploration.(Thematic Instruction, n.d.). The Journal of Technology Studies (JOTS), (n.d.), suggests that some schools use an integrated curriculum to make education relevant and keep students interested in school. (JOTS v25n2 - Models of Curriculum Integration, n.d.).

The MOETT, (2014), primary school curriculum teachers' guide states that the new curriculum:

- focuses on nine subject areas within an integrated, thematic approach

- emphasizes cross-curricular development of Literacy and Numeracy

- infuses Information and Communication Technologies (ICTs)

- $\quad$ prioritizes assessment for learning

- develops values, including Health and Family Life Education, and 
- promotes delivery of explicit, systematic differentiated instruction to meet the needs of a range of students.

\subsection{Core Content Areas}

The nine core subject areas identified in the curriculum are Agricultural Science, English Language Arts, Mathematics, Physical Education, Science, Social Studies, Spanish, Values, Character and Citizenship Education (VCCE), and visual and performing arts (VAPA). (Primary Curriculum Guides, 2014). For each subject area, the content and skills that students are expected to acquire, along with the behavioral tendency they are supposed to demonstrate have been identified and sequenced in learning outcomes. (MOETT, pg. 3).

\subsection{Themes}

The curriculum specifies seven broad themes for each level. Each theme is further divided into subthemes.

Table 1. Integrative themes for MOE Primary curriculum

\begin{tabular}{ll}
\hline Class & Themes \\
\hline Infants 1 & Me and My World \\
Infants 2 & My sense of belonging \\
Standard 1 & My country: The people and culture of Trinidad and Tobago \\
Standard 2 & My country: The environment of Trinidad and Tobago \\
Standard 3 & Our Region the Caribbean \\
Standard 4 & A world of change \\
Standard 5 & Putting it all: Projects and Subject Learning Becoming a global citizen. \\
\hline
\end{tabular}

Table 1 lists the seven broad themes identified in the primary curriculum by class levels. These themes develop further into subthemes.

Table 2. Themes and sub-themes

\begin{tabular}{|c|c|c|c|c|c|c|}
\hline \multicolumn{7}{|c|}{ Infant One: Me and My World } \\
\hline People & Places & Things & Activities & Activities & \multicolumn{2}{|c|}{ People } \\
\hline Myself, My & My Home, & Things Around & I Learn, I Play & My Big & My & Health \\
\hline Family and & School and & $\mathrm{Me}$ & and I Work & Days and & and & Well- \\
\hline Friends & Community & & & Celebrations & being & \\
\hline \multicolumn{7}{|c|}{ Standard One: My Country: The People and Culture(s) of Trinidad and Tobago } \\
\hline \multirow[t]{2}{*}{ Mapping } & Term I & Term 2 & Term 3 & Food & \multicolumn{2}{|c|}{ Activities } \\
\hline & & Leisure, & & & & \\
\hline My Country: & The Past & Work and & The culture & Things I Eat & \multicolumn{2}{|c|}{ My Celebrations } \\
\hline The People & & Entrepreneurs & & & & \\
\hline and Culture & & hip & & & \multirow{2}{*}{\multicolumn{2}{|c|}{$\begin{array}{l}\text { My Songs, Art, } \\
\text { Dance and Drama }\end{array}$}} \\
\hline of Trinidad & & & & & & \\
\hline and Tobago & & & & & & \\
\hline
\end{tabular}

Table 2 shows the sub-themes for Infant-One and Standard-One.

MOETT further emphasizes a balanced approach to literacy in the National Primary curriculum with integration of the other core subject areas. 


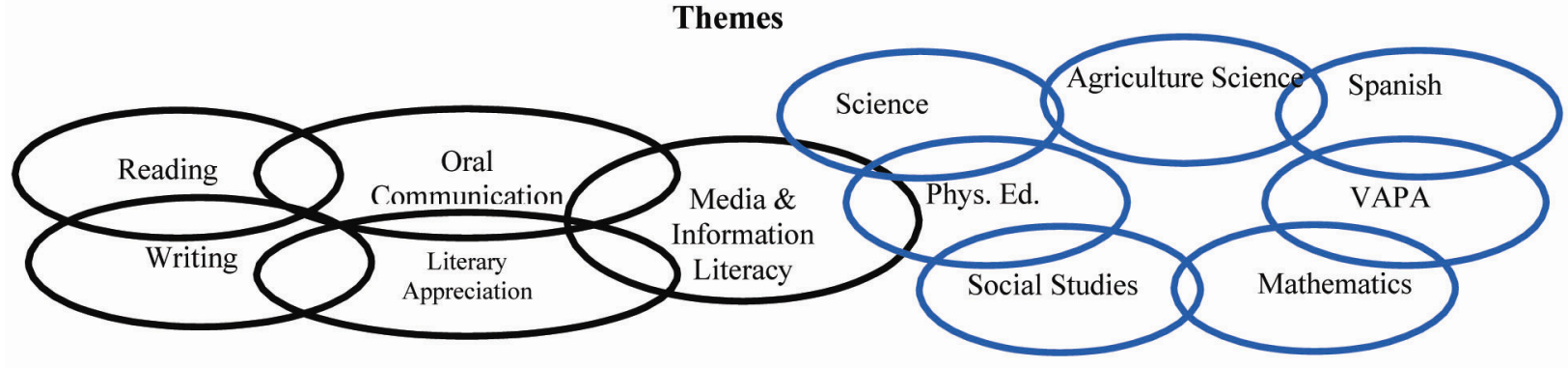

English Language Arts Skills

Figure 1. Balanced Approach to Literacy in the National Primary Curriculum

Figure 1 demonstrates literacy across the curriculum, using a balanced approach. English Language Arts skills identified as Reading, Writing, Oral Communication, Literary Appreciation, Media, are integrated with the other subject areas of Agricultural Science, Science, Social Studies, VAPA, Mathematics, Spanish and Physical Education.

\subsection{The Problem Under Study}

The new curriculum was introduced in primary schools for the 2013-2014 school year for implementation throughout the public schools of Trinidad and Tobago. However, one year after the introduction, a large number of teachers in schools across the nation (approximately 50\%) are resisting the implementation. One of the reasons echoed by teachers in various schools is the lack of professional development to empower them to implement the curriculum. A great majority of teachers across the 537 primary establishments further claim, when interviewed, that demonstrations of how to differentiate, assess, and integrate Information and Communications Technology (ICT) with a thematically integrative focus were not appropriately provided.

The indicated problem is important in the area of curriculum implementation for all teaching colleges in Trinidad and Tobago. UTT, one of the providers, prepare teachers to work in primary and secondary schools. Prospective teachers practice in the schools twice per year, for varying periods. During these practicum sessions, prospective teachers must work with directing teachers to deliver planned lessons to students in schools. Additionally, in-service prospective teachers are placed in schools, in their substantive positions, while pre-service prospective teachers enter the pool of teachers to supply education to our nation's schools. Therefore, in preparing teachers, UTT must ensure that prospective teachers can work with and are proficient in the delivery of current curriculum.

The Association of Teacher Educators (ATE), (2008), has listed nine standards, to help all teacher candidates and other school personnel impact student learning. The first of nine standards addresses teaching. It states that teacher educators should: "Model teaching that demonstrates content and professional knowledge, skills, and dispositions reflecting research, proficiency with technology and assessment and accepted best practices in teacher education." (ATE, n.d.). According to ATE, (2008) for teacher educators to impact the profession, they should successfully model appropriate behaviors in order for those behaviors to be observed, adjusted, replicated, internalized, and applied appropriately to learners of all levels and styles. Modeling means exhibiting behavior that is observed and imitated by others (Kauchak \& Eggen, 2005, p. 396). Effective modeling of desired practices is at the heart of successful teacher education programs at pre-service and in-service levels. Teachers are powerful and meaningful role models for students at all levels, and the way they act influences both learning and motivation (Bandura, 1989). Modeling of behavior relates to teaching, service, and scholarly productivity. Teacher educators must use research-based, proven best practices for those behaviors to be appropriately applied. (ATE, n.d.).

This study builds on previous studies conducted by this researcher and others in the field of differentiation and assessment (John \& Joseph, 2014; John \& Joseph, 2015), in which prospective teachers were trained to implement differentiation and assessment in schools with success. The report differs from those previous reports since it seeks to show that use of the new curriculum is critical, and an important part of achieving successful outcomes. This study aims at explicitly and systematically training prospective teachers to implement the national curriculum effectively.

\section{Literature Review}

\subsection{Integrated curriculum}

A basic definition offered by Humphreys (Humphreys, Post, and Ellis 1981) states that an integrated curriculum is one in which children broadly explore knowledge in various subjects related to certain aspects of their environment. Curriculum Associates, (n.d.) makes associations among the humanities, communication arts, natural sciences, 
mathematics, social studies, music, and art. Skills and knowledge are developed and applied in more than one area of study. In keeping with this definition, Shoemaker defines an integrated curriculum as education that is organized in such a way that it cuts across subject- matter lines, bringing together various aspects of the curriculum into meaningful association to focus upon broad areas of study. It views learning and teaching in a holistic way and reflects the real world, which is interactive. (Curriculum Associates, n.d.).

\subsection{Thematic units}

A thematic unit is the organization of a curriculum around a central theme. In other words it's a series of lessons that integrate subjects across the curriculum, such as math, reading, language arts, social studies, science etc., that all tie into the main theme of the unit. Each activity should have a main focus toward the thematic idea. A thematic unit is much broader than just choosing a topic. (What-Is-A-Thematic-Unit.htm, n.d.).

\subsection{Differentiating within Thematic units}

Scholastic.com, (n.d.) states that differentiating instruction within a thematic unit based on reading levels differs from attempting to individualize instruction within a non-thematic unit. When differentiating instruction, the teacher may select texts that are thematically related at various reading levels (easy readability, medium readability, challenging readability) that are each related to a common idea. By using related texts, the teacher easily creates essential questions that are relevant to all three leveled texts within a given thematic unit. Essential questions search for deeper meaning and promote the development of critical thinking skills. Good essential questions are open-ended and normally do not have a single correct answer, require students to call upon both content knowledge and background knowledge, are thought provoking, meaningful to students, and at times controversial. Good essential questions encourage an exploration of ideas and promote collaborative thinking. It allows the teacher to rejoin guided small groups and have whole class discussions focusing on the same issues. Each team can address those inquiries as they relate to their background knowledge and their particular text.

\subsection{Why thematic Units}

What-Is-A-Thematic-Unit.htm, (n.d.) suggests that thematic units increase students interest, help students understand connections, expand assessment strategies, keep students engaged, compact the curriculum, save teachers time because it incorporates all subjects and draw on connections from the real world and life experiences. Fundamental components in thematic units are:

1. The Theme - Select the topic of the unit based on curriculum standards, student interests or student experience.

2. Grade Level - Select the appropriate grade level.

3. Objectives - Identify the specific objectives to be mastered during the unit.

4. Materials - Determine the materials for use throughout the unit.

5. Activities - Develop the activities for the thematic unit. Make sure to cover activities across the curriculum.

6. Discussion Questions - Create a variety of discussion questions to help students think about the theme of the unit.

7. Literature Selections - Select a variety of books that correlate with the activities and central theme of the unit.

8. Assessment - Evaluate student progress throughout the unit. Measure student growth through rubrics or other means of assessment. (What-Is-A-Thematic-Unit.htm, n.d.).

\subsection{Integration methods}

Fogarty (1991) states that there are ten methodologies of integration, contained within three forms.

2.5.1 Form one: Integration within a single discipline

1. Fragmented - This methodology utilizes a traditional curriculum design that separates topics and courses into distinct disciplines. (Integration of the Disciplines - Fragmented. (n.d.)).

2. Connected - The connected methodology focuses on the details, refinements, and interconnections within an individual discipline.

3. Nested Integration - takes advantage of natural combinations by explicitly making connections or creating combinations. (Fogarty, 1991) 


\subsubsection{Form two: Across the Disciplines}

1. Sequence - The sequence methodology teaches topics and units independently but arranges and sequence them to provide a framework for related concepts. (Fogarty, 1991)

2. Shared - A shared model of integration of curriculum brings two distinct disciplines together into a single focus. (Fogarty, 1991)

3. Webbed - Webbed curricula use a thematic approach to integrating subject matter. Broad themes provide a greater opportunity for teachers of various disciplines to find common topics, concepts, and skills. (Fogarty, 1991)

4. Threaded - The threaded approach to integration is a meta-curricular approach. Big ideas are enlarged. The methodology threads thinking, social, skills, graphic organizers, technology, and Gardner's multiple intelligence approaches to thinking throughout all disciplines. (Fogarty, 1991)

5. Integrated Model - An integrated methodological approach arranges interdisciplinary topics around overlapping concepts and developing patterns. (Fogarty, 1991).

2.5.3 Form three: Within and Across Learners

1. Immersed - The immersed methodology of integration focuses all curricular content on interest and expertise. With this methodology, integration takes place within the learners, with little or no outside intervention

2. Networked - A networked methodology creates multiple dimensions and directions of focus. Like brainstorming, it provides various ideas and ways of discovering. (Fogarty, 1991; http://oregonstate.edu/instruction/ed555/zone3/network.htm)

\section{Method}

\subsection{Purpose of the Study}

The purpose of this study was to investigate whether explicit and systematic instruction using the integrated thematic curriculum will increase the ability of prospective teachers to meet better the needs of students in the inclusive environment. The study will further investigate whether prospective teachers can model effective instruction for diverse students, demonstrate appropriate subject matter content, and show a variety of instructional and assessment methods including the use of technology.

\subsection{Null Hypotheses}

$H_{0 . x}$ : There is no difference in the performance, measured by examined-field-teaching, between prospective teachers receiving explicit and systematic training to implement the new thematic, integrated curriculum and prospective teachers who did not train.

$H_{0 \cdot y}$ : There is no difference in preparedness, measured by on-going-preparation, between prospective teachers explicitly and systematically trained to implement the new thematic, integrated curriculum and prospective teachers who did not train.

$H_{0 . z}$ : There is no difference in directing-teacher-evaluation, between prospective teachers explicitly and systematically trained to implement the new thematic, integrated curriculum and prospective teachers who did not train.

$H_{0 . a}$ : There is no difference in pupils' instructional level improvement on Ekwall Shanker Reading Inventory (ESRI), between prospective teachers explicitly and systematically trained to implement the new thematic, integrated curriculum and prospective teachers who did not train.

\subsection{Research Design}

Table 3. Nonequivalent-groups Posttest-only design

\begin{tabular}{|c|c|c|}
\hline Group & Intervention & Posttest \\
\hline $\begin{array}{l}\text { A - (Experimental group) Year } 4 \\
\text { students in SPED specialization. }\end{array}$ & $\begin{array}{l}\text { Professional development in the use } \\
\text { of the 'new' thematic integrated } \\
\text { curriculum of MOETT }\end{array}$ & $\begin{array}{l}\text { PRAC } 4002 \text { examination (on-going } \\
\text { preparation and examined field } \\
\text { teaching) }\end{array}$ \\
\hline $\begin{array}{l}\text { B - (Control group) Year } 4 \text { students } \\
\text { in SPED specialization }\end{array}$ & - & $\begin{array}{l}\text { PRAC4002 (on-going preparation } \\
\text { and examined field teaching) }\end{array}$ \\
\hline
\end{tabular}


Table 3 illustrates a nonequivalent-Group Posttest-only design with Group A being the experimental group, receiving professional development using the new curriculum, and Group B being the control group receiving no professional development. UTT practicum advisors conducted professional development during PRAC4002: Final Practice, classroom sessions prior to field teaching. Group B: Control group did not receive professional development in the use of the new curriculum.

\subsection{Population and Sample}

The population for the study comprised $(\mathrm{N}=786$ prospective teachers (PT) year- 3 and year- 4 cohort groups (in-service/pre-service). Participants' enrollment reflects B.Ed. degree specialization in Special Needs and Primary Education, Primary Education and Early Childhood Care Education (ECCE) at UTT.

Participants for this study, $\mathrm{n}=42$ prospective teachers ( 38 females and four males), were purposively selected from a larger sample of 109 prospective teachers (105 females and four males). These participants successfully completed the following courses in 2014 - 2015. SPED3001 -Teaching English Language Arts I, SPED3006: Teaching English Language Arts II to students with mild to moderate disabilities, PRAC3002: Deepening the field teaching experience, PRAC4001: Preparing for final practicum, SPED4001: Social Studies, AGSC3001: Agriculture Science, SPAN4002: Integrated Spanish, HFLE3001: Health and Family Life Education, and SCIE4002: Life and Earth Science. Prospective teachers must also be registered for PRAC4002: Preparing for final practice. Having successfully completed the courses listed gave PT the ability to integrate the curriculum core courses. Being registered in PRAC4002 enabled PT to receive/or not receive professional development in the new primary curriculum.

Thirty prospective teachers meeting the above criteria were randomly assigned to 10 schools and 30 teachers that used the thematically, integrated curriculum. These prospective teachers formed the experimental group. Twelve prospective teachers were randomly assigned to four schools and 12 teachers that partially used or did not use the new curriculum. These subjects formed the control group.

\subsection{Research Site}

The study site included 20 of 537 primary schools in Trinidad and Tobago, 16 'inclusive' schools (students with/without mild to moderate exceptionalities) and four special schools. The sites included 20 principals, 42 directing teachers, and 343 students in 42-targeted primary classes from Infants One to Standard Three.

\subsection{Variables}

The dependent variable in this study was prospective teachers ability to better meet student needs while integrating the thematic curriculum, operationalized by four student scores in prospective teacher performance obtained from ongoing-preparation, examined-field-teaching, directing-teacher evaluation and instructional-grade-level improvement on ESRI; triangulated with data from prospective teacher perceptions of their teaching shown in surveys.

\subsubsection{On-going-preparation}

Table 4. Ongoing Preparation Rubric [15\%]

$$
\begin{array}{ll}
\hline \mathbf{1 3}-\mathbf{1 5 \%} & \begin{array}{l}
\text { Fully prepared for field-orientation and field-teaching visits. Records of teaching and } \\
\text { reflections well maintained in a Practicum Folder and available at all times. } \\
\mathbf{9 - 1 2 \%}
\end{array} \\
& \begin{array}{l}
\text { Mostly prepared for field-orientation and field-teaching visits. Records of teaching } \\
\text { and reflections maintained in a Practicum Folder, but partially incomplete. }
\end{array} \\
\mathbf{5 - \mathbf { 8 } \%} & \begin{array}{l}
\text { Mostly unprepared for field-orientation and field-teaching visits. Records of teaching } \\
\text { and reflections not readily available or are mostly incomplete. }
\end{array} \\
\mathbf{0 - 4 \%} & \begin{array}{l}
\text { Always unprepared for field-orientation and field-teaching visits Records of teaching } \\
\text { and reflections not available. }
\end{array}
\end{array}
$$

The evaluation of this assignment was based on specific criteria identified in the on-going preparation rubric, Table 4 . Prospective teachers were expected to be fully prepared each day while on field teaching. All unit and lesson plans were submitted to and approved by the lecturers in practice before these lessons were taught. They were kept in binders and made available for scrutiny during field visits. 


\subsubsection{Examined field teaching}

Table 5. Unit Plan Scoring Guide, (n.d.)

\begin{tabular}{|c|c|}
\hline Elements & Distinguished (3) \\
\hline $\begin{array}{l}\text { Introduction/ } \\
\text { General } \\
\text { Information }\end{array}$ & $\begin{array}{l}\text { Complete title page; rationale for } \\
\text { teacher and importance (goal and } \\
\text { relevance) to the learners; provides } \\
\text { areas of integration. }\end{array}$ \\
\hline Standards/Anchors & $\begin{array}{l}\text { MOETT Content Standards are } \\
\text { listed and fully reflect a direct } \\
\text { correlation to individual lesson } \\
\text { objectives. }\end{array}$ \\
\hline Unit Goals & $\begin{array}{l}\text { Performance-based; written with } \\
\text { general condition and performance } \\
\text { (learning outcome). }\end{array}$ \\
\hline $\begin{array}{l}\text { Essential } \\
\text { Questions } \\
\text { (EQs) }\end{array}$ & $\begin{array}{l}\text { Unit-specific; clearly described; EQ(s) } \\
\text { help students conceptualize the theme of } \\
\text { the lesson and challenge students to } \\
\text { think critically. EQ(s)also prompt } \\
\text { students to develop a plan of action and } \\
\text { require them to construct their } \\
\text { knowledge by connecting the topic to } \\
\text { what they've learned previously. }\end{array}$ \\
\hline Pre-assessment & $\begin{array}{l}\text { Pre-assessment aligned with lesson } \\
\text { objectives and adapted, as needed. }\end{array}$ \\
\hline $\begin{array}{l}\text { Lesson } \\
\text { Plans } \\
\text { (Content) }\end{array}$ & $\begin{array}{l}\text { Contains at least three ( } 3) \text { lesson } \\
\text { plans that follow all elements } \\
\text { contained in the lesson plan rubric; } \\
\text { use diverse instructional } \\
\text { methods/strategies; progress in a } \\
\text { logical order. }\end{array}$ \\
\hline
\end{tabular}

Student ID:

Proficient (2)

Partially complete title page; rationale or importance; integration areas proposed, but not detailed.

MOETT Content

Standards are listed and partially correlate to individual lesson

objectives.

Performance-based; lacks condition, but provides learning outcome.

Unit-specific; described; $\mathrm{EQ}(\mathrm{s})$ help students conceptualize the theme of the lesson and challenge students to think critically.

Pre-assessment marginally aligned and adapted, as needed.

Contains at least three (3) moderately diverse lesson plans with all elements or three diverse lessons with one or two elements missing; progress in a logical order.
Basic (1)

Minimal title page lacking

at least three (3) critical parts with rationale and/or importance that miss the mark; no evidence of integration. MOETT

Content

ards listed with little or no correlation to individual lesson objectives.

Condition missing;

performance is not assessable or unclear.

$\mathrm{EQ}(\mathrm{s})$ are listed but not described; encourage some higher order thinking.

Pre-assessment unclear and not adapted for all learners.

Contains at least three (3) minimally diverse lesson plans with all elements or three (3) moderately diverse lessons with one (1) or two

(2) elements missing; lack logical progression.

\author{
Unsatisfactory (0) \\ Minimal title page lacking \\ at least three (3) critical \\ parts with rationale and/or \\ importance that miss the \\ mark; no evidence of \\ integration.

\section{MOETT Content} \\ Standards are not \\ specifically identified and \\ listed. \\ No unit goals provided.
}

\begin{tabular}{l} 
Student ID: \\
\hline Elements \\
\hline \\
Integration of \\
Resources and \\
Technology
\end{tabular}

Technology

Integration of other subject areas

Differentiated Learning Activities

Summative Assessment/PostAssessment

Reflection

\begin{tabular}{|c|c|}
\hline Distinguished (3) & Profic \\
\hline $\begin{array}{l}\text { A range of resources, materials and } \\
\text { technology are effectively } \\
\text { integrated into the context of the } \\
\text { lesson, engaging to learners and } \\
\text { provide for optimal student } \\
\text { learning. Additional resources are } \\
\text { listed for extended learning } \\
\text { activities. }\end{array}$ & $\begin{array}{l}\text { Resources, materials and } \\
\text { technology are utilized, } \\
\text { appropriate for the learners } \\
\text { and provide for optimal } \\
\text { student learning. }\end{array}$ \\
\hline $\begin{array}{l}\text { Lesson linked at least } 5-6 \text { of the } \\
\text { other core subjects in the } \\
\text { curriculum. }\end{array}$ & $\begin{array}{l}\text { Lesson linked at least } 3-4 \\
\text { of the other core subjects in } \\
\text { the curriculum. } \\
\text { Snecific activities that }\end{array}$ \\
\hline $\begin{array}{l}\text { Specific activities that differentiate } \\
\text { the content, process, product, and/or } \\
\text { learning environment are designed to } \\
\text { provide advanced achievement for } \\
\text { all learners. Research-based } \\
\text { strategies are effectively described to } \\
\text { challenge all learners. }\end{array}$ & $\begin{array}{l}\text { hat } \\
\text { ntent, } \\
\text { nt or } \\
\text { e } \\
\text { learners. } \\
\text { ategies } \\
\text { eet the } \\
\text { s. }\end{array}$ \\
\hline $\begin{array}{l}\text { Assessment matches lesson } \\
\text { objectives; higher-thinking skills } \\
\text { tied to pre-assessment; answers } \\
\text { provided. }\end{array}$ & $\begin{array}{l}\text { atches } \\
\text { ves; limited } \\
\text { g skills tied } \\
\text { lent; } \\
\text { ded. }\end{array}$ \\
\hline $\begin{array}{l}\text { Thoroughly analyzes evidence of } \\
\text { student learning. A reflection of } \\
\text { teacher performance encompasses } \\
\text { the domains of planning, instruction, } \\
\text { environment and professionalism. All } \\
\text { areas of performance receive in- } \\
\text { depth objective reflection. Data or } \\
\text { products are utilized; describes } \\
\text { relevant modifications. }\end{array}$ & $\begin{array}{l}\text { Analyzes evidence of } \\
\text { student learning and teacher } \\
\text { performance in planning, } \\
\text { instruction, environment } \\
\text { and professionalism. All } \\
\text { areas of performance } \\
\text { receive objective reflection; } \\
\text { provides relevant } \\
\text { modifications. }\end{array}$ \\
\hline
\end{tabular}

Basic (1)

Resources, materials and technology are utilized to support instruction.

Lesson linked at least 1- 2 of the other core subjects in the curriculum.

General activities that differentiate the content, process, product, and/or learning environment are identified.

Detail is lacking in one or more of the critical areas.

Assessment matches lesson objectives, but only includes knowledge and comprehension items; answers not included.

Partially analyzes student learning and teacher performance in planning, instruction, environment and professionalism. Some reflection is evident; modifications identified.
The EQ(s) is too simple and will not help students think critically.

No evidence of preassessment.

No lesson diversity (all three [3] are lectures or all three [3] are discussion, etc.); lack logical progression 
Table 5: Unit Plan Scoring Guide reflected scores for field-teaching, based on specific criteria identified in the thematic, integrated instruction rubric that identified the level of proficiency for each PT. Prospective teachers planned, delivered, and were evaluated on lessons taught over the six-weeks period. On field-teaching days, each prospective teacher taught two (2) pre-planned lessons by him/herself while being observed by his/her directing teacher or lecturer in practice.

3.6.3 Directing-teacher evaluation

Table 6. Directing-Teacher evaluation rubric of Thematic Integrative Unit

Name of Student - Date
Name of the Thematic Integrative Unit

Tell me about the highlight of this unit.

What piece of the lesson did you find most beneficial? Least? and Why?

What question were you unable to answer?

Identify at least three areas that need improvement.

\section{Prospective Teacher-Directing Teacher Conference}

Scale: 1 = Unsatisfactory 3 = Satisfactory $; 5=$ Excellent

\begin{tabular}{ll}
\hline Disposition toward the unit & 12345 \\
Conceptual understanding & 12345 \\
Goal achievement & 12345 \\
Independence in task completion & 12345 \\
Research skills presented & 12345 \\
Use of technology and other resources & 12345 \\
Ability to establish conceptual priorities & 12345 \\
Problem solving ability & 12345 \\
Differentiation & 12345 \\
Assessment & 12345 \\
Integration of other core subjects & 12345 \\
Accommodations for all learners & 12345 \\
\hline
\end{tabular}

Table 6 assessed the PT perception of the lesson taught and the directing teacher's perception of the delivery of the lesson/unit. Each PT reflected on his/her practice, giving explanations where necessary.

3.6.4 Instructional Level Improvement

Prior to field teaching, all PT visited their assigned school and assessed students in their classes using the Eckwall/Shanker Reading Inventory (ESRI). Students were given the Graded Word List (GWL) to find a quick approximation of the student's reading levels. This test established a starting level for the Reading Passages Test or established the student's sight vocabulary level. (ESRI, 2013). Prospective teachers started with the PP level and stopped the testing after three incorrect responses. The levels indicated were $0-1$ error $=$ Independent level; 2 errors $=$ instructional level; 3 or more $=$ frustration.

Prospective teachers administered the Reading Passages test to determine the student's independent, instructional and frustration levels for oral and silent reading. The test was also used to determine the level at which students can understand the material read to them. Analysis of this test can determine the students understanding of vocabulary, basic sight words, phonics and decoding skills, and comprehension ability. (ESRI, 2013). The ESRI was administered at the end of the practicum assignment, week 11, to gauge success or lack thereof of PT meeting the needs of students in reading.

\subsection{Intervention}

Based on the research and best practices encountered in the literature on teaching thematic integrated curriculum, professional development included familiarization with the new curriculum. The intervention approach chosen combined reinforcement training in (a) diagnostic assessment and data analysis, (b) differentiation using the thematic 
integrated curriculum, (c) unit and lesson plan creation using the content from the new curriculum (d) thorough study/familiarization of the new curriculum.

\subsubsection{Schedule.}

Table 7. Training schedule for prospective teachers

\begin{tabular}{lllllllllllll}
\hline Weeks & W1 & W2 & W3 & W4 & W5 & W6 & W7 & W8 & W9 & W10 & W11 & W12 \\
\hline PRAC4002 & C & C & C & F & C & F & F & F & F & F & F & R \\
\hline
\end{tabular}

$W=$ Week, $C=$ Classroom sessions, $F=$ Field Teaching Practice, $R=$ Reflection/Instruction

Table 7 lists the twelve weeks session for the course PRAC4002: Final Practice. Prospective teachers were explicitly trained in developing unit and lesson plans for preparation to implement the new curriculum.

\subsubsection{Training}

Prospective teachers learnt how to prepare thematic integrated lessons using the content of the MOETT curriculum toolkits. Prospective teachers were familiarized with the contents of the toolkits according to their practicum placement.

\section{Instructional Toolkit}

- Integrated Learning Units and Learning Plans for all Themes

- Core skills Learning Plans in Subject Area

- Scope and Sequence: Mathematics

- Scope and Sequence: Science

- Assessment Rubrics for general performance areas

- Assessment Rubrics for subject specific skills and tasks

Figure 2. Instructional Toolki2t

Figure 2 illustrates the organization of all toolkits. Prospective teachers were given explicit instruction on how to develop plans for their assigned classes.

\section{Learning Unit 2: The People and Culture of the Past}

Class: Standard One

Theme: My Country: The Past

Estimated time frame: 2 weeks

\section{Context:}

The people who came to Trinidad and Tobago in the past (1400-1900) made significant contributions which provided a foundation upon which our nation was built. Understanding the important role that these early settlers and their descendants played, allows students to fully appreciate the country's achievements to present day. It also explains the diversity that exists in Trinidad and Tobago. When students develop an understanding and an appreciation of the different people who arrived in the past and the contributions they made, it stimulates their own desire to become respectful citizens who are ready and willing to make their own contributions to continue building their nation.

\section{Outcomes:}

At the end of this learning experience students will:

1. demonstrate a basic knowledge of Trinidad and Tobago's history from re-discovery to 1900s

2. describe major changes that took place in their country's history

3. construct models of some artifacts used by people in the early days

4. identify outstanding personalities in their country's history and their contributions to nation building

5. compare the past to the present

6. display proficiency in using verbal and written communication skills. 


\section{Learning Plans:}

- The People Who Came

- Creating Models of Cultural Artifacts

- Agricultural Practices of the Past

- Outstanding Personalities of the Past

- Comparing the Past to the Present

\section{Resources:}

Copies of Anticipation Guide, pencils, computers/computer and projector, internet/DVD with documentary/pictures of early history of Trinidad \& Tobago, copies of graphic organizer, markers, writing prompts, pictures/samples of artifacts, labels for artifacts, cloze questions worksheet, available/discarded materials for making models, display corner, student portfolio, Bristol board/chart paper, masking tape, student checklist for chart-making, books/articles and pictures outstanding personalities of the past, color paper for scrapbooks, name cards, camcorder, DVDs, *search keywords 'History of Trinidad and Tobago

\section{Assessments:}

Rubrics for: informational writing, video documentary, oral presentation

Checklist for: chart-making, scrapbook-making, observation of participation, co-operation, and collaboration. Students' portfolios

Suggested websites:

Note: Checklists and rubrics cited may be adjusted to suit criteria and level of students.

Figure 3. Unit plan for Standard One class provided by MOETT in its toolkit. (Primary Curriculum, 2014).

\subsubsection{Timetable}

Prospective teachers received training on timetabling specified by the MOETT framework. The nine subject areas (Mathematics, English Language Arts, Science, Social Studies, Visual and Performing Arts, Physical Education, Agricultural Science, Values, Character and Citizenship Education and Spanish) HFLE and ICT to be infused throughout the subjects. 50\% of the time should be spent on English Language Arts and Mathematics, to include Literacy and Numeracy. The other 50\% to be dedicated to the other seven subjects (Primary Curriculum, 2014).

\section{Results}

Table 8. Paired t-test for PT using the 'new' thematic, integrated curriculum (Experimental vs. Control groups)

\begin{tabular}{|c|c|c|c|}
\hline Variables & $\mathrm{T}$ & p-value & \\
\hline Field teaching & 9.881094 & $\mathrm{P}<0.00001$ & $\begin{array}{l}\text { The result is significant } \\
\text { at } \mathrm{p}=.05 . \mathrm{We} \\
\text { therefore reject the } \mathrm{H}_{0 \mathrm{x}} \\
\text { hypothesis. }\end{array}$ \\
\hline On-going preparation & 2.833262 & $\mathrm{P}=0.006929$ & $\begin{array}{l}\text { The result is significant } \\
\text { at } \mathrm{p}=.05 . \mathrm{We} \text { therefore } \\
\text { reject the } \mathrm{H}_{0 \mathrm{y}} \text { hypothesis. }\end{array}$ \\
\hline Directing-Teacher evaluation & 2.341189 & $\mathrm{P}=0.011908$ & $\begin{array}{l}\text { The result is significant } \\
\text { at } \mathrm{p}<0.05 \text {. We therefore } \\
\text { reject the } \mathrm{H}_{0 \mathrm{z}} \text { hypothesis. }\end{array}$ \\
\hline Instructional level improvement on ESRI & 4.670502 & $\mathrm{P}=0.000034$ & $\begin{array}{l}\text { The result is significant } \\
\text { at } \mathrm{p}<0.05 \text {. We therefore } \\
\text { reject the } \mathrm{H}_{0 \mathrm{a}} \text { hypothesis. }\end{array}$ \\
\hline
\end{tabular}

Table 8 shows at $\sigma=.05$ (Confident Interval of $95 \%$ ), $p=.006929$, which is less than alpha. Indicating that there is a significant difference in on-going preparation of prospective teachers who are trained to use the national primary school curriculum compared to those who are not.

Field teaching reflected that at $\sigma=.05$ (Confident Interval of $95 \%$ ), $\mathrm{p}<.00001$. This result indicates that for the experimental group A, field teaching was significantly better than that of group B, the control group.

Directing teacher evaluation reflected that at $\sigma=.05$ (Confident Interval of 95\%), $\mathrm{p}=.011908$. This result indicates that directing teachers evaluated experimental group A significantly higher than the control group B. 
Instructional level improvement on ESRI indicated that at $\sigma=.05$ (Confident Interval of $95 \%$ ), $\mathrm{p}=.000034$. This result indicates that student's instructional level improved in the experimental group A, significantly over the control group B.

\subsection{Quantitative Results}

Table 8 shows at $\sigma=.05$ (Confident Interval of $95 \%$ ), $\mathrm{p}=.006929$, which is less than alpha. Indicating that there is a significant difference in on-going preparation of prospective teachers who are trained to use the national primary school curriculum compared to those who are not.

Field teaching reflected that at $\sigma=.05$ (Confident Interval of $95 \%$ ), $\mathrm{p}<.00001$. This result indicates that for the experimental group A, field teaching was significantly more effective than that of group B, the control group.

Directing teacher evaluation reflected that at $\sigma=.05$ (Confident Interval of 95\%), $\mathrm{p}=.011908$. This result indicates that directing teachers evaluated experimental group A significantly higher than the control group B.

Instructional level improvement on ESRI indicated that at $\sigma=.05$ (Confident Interval of $95 \%$ ), $\mathrm{p}=.000034$. This result indicates that student's instructional level improved in the experimental group A, significantly over the control group B.

\subsubsection{Qualitative results}

The quantitative data analysis triangulated with the qualitative data gathered from a survey instrument. The results show that as prospective teachers implemented the new thematic, integrated curriculum after training $91 \%$ felt that they met student's needs in the experimental group, while only $73 \%$ felt that they met students' needs in the control group. Both groups assessed students in reading using the ESRI and used the assessment data to make instructional decisions for teaching and learning. However results from the difference scores of instructional levels using the ESRI indicated that a significant difference existed in improved instructional levels of students taught by the experimental group compared to the students taught by the control group. This assessment data helped both experimental and control groups to form semi-permanent small groups by instructional levels. The data also assisted prospective teachers to carefully select matched instructional materials from the thematic, integrated curriculum to deliver appropriate instruction based on the themes and nine disciplines.

Prospective teachers who received instruction to implement the new curriculum perceived that they met the needs of students. Overall, $98 \%$ of the prospective teachers in the experimental group reported that student engagement increased. Eighty-eight percent of the prospective teachers in the experimental group perceived that they met the needs of their students while demonstrating knowledge of the integrated thematic curriculum.

Table 9. How "experimental group" of PT perceived that students' needs were met.

\begin{tabular}{ll}
\hline How PT perceived Needs Met & $\%$ PT \\
& Giving positive responses \\
\hline Improvement in reading, math and science & 0.83 \\
Increased engagement & 0.93 \\
Heighten motivation & 0.83 \\
Varying Skill Development & 0.67 \\
Enabling greater retention of information & 0.80 \\
Catered for all learners via differentiation and assessment & 1.00 \\
Covered more content areas & 1.00 \\
Developed lessons in a wider area allowing for greater curriculum access & 1.00 \\
Aided with integration of ICT, literacy and numeracy & 1.00 \\
Developed critical thinking skills & .83 \\
Helped students make connections to real world situations & 1.00 \\
Built and maintained heightened interest & .93 \\
Fostered more interaction & 1.00 \\
Use multiple intelligence & 1.00 \\
\hline
\end{tabular}

Based on Survey responses, Table 9 represents the percentage of PT (experimental group) who felt that they met the students' needs. 


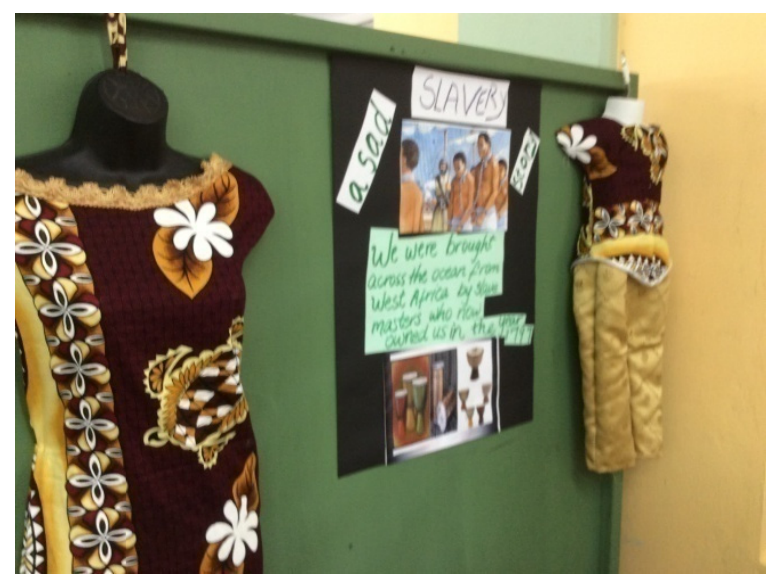

Figure 3. Writing activity around the theme "My Country: My Past"

Figure 3 illustrates a writing center activity using one of Trinidad and Tobago's local calypso as the catalyst.

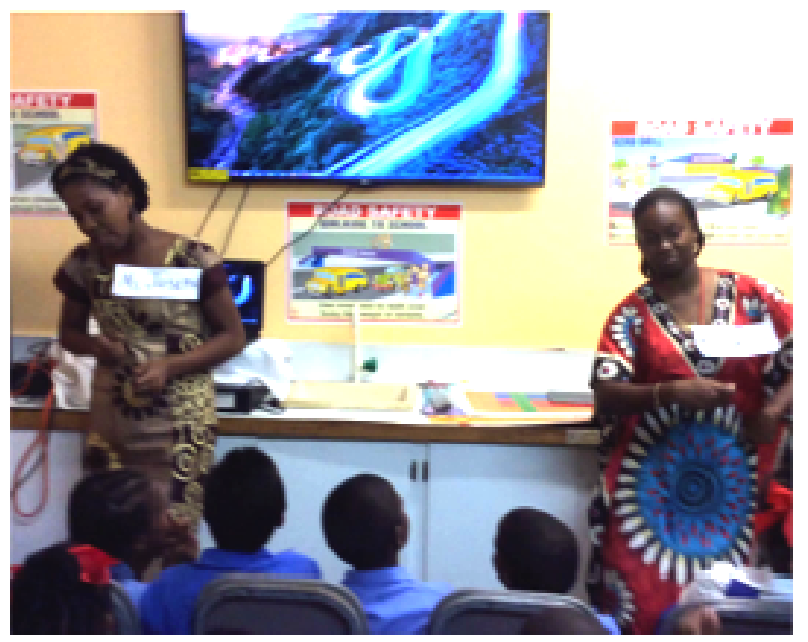

I'm a Slave

"I'm a slave from a land so far

I was caught and brought here from Africa ...

It was licks like fire, from de white Slave Master..."

Sparrow, (1995)

https://www.youtube.com/watch? $v=m_{-}$lr_rHdSuQ, (n.d.)

Figure 4. Shared Reading integrated with VAPA to audio "I'm a Slave", (Sparrow, 1995)

In Figure 4, prospective teachers used the calypso "I'm a slave" by Mighty Sparrow (1995) to introduce the shared reading lesson activity, integrating oral language with VAPA, dancing to the rhythm of the calypso. 
Table 9. How "control group" perceived that needs is met

\begin{tabular}{ll}
\hline How PT perceived Needs Met & $\%$ PT \\
& Giving positive responses \\
\hline Improvement in reading, math and science & $83 \%$ \\
Increased engagement & $83 \%$ \\
Heighten motivation & $75 \%$ \\
Varying Skill Development & $67 \%$ \\
Enabling greater retention of information & $67 \%$ \\
Catered for all learners via differentiation and assessment & $83 \%$ \\
Covered more content areas & $75 \%$ \\
Developed lessons in a wider area allowing for greater curriculum access & $83 \%$ \\
Aided with integration of ICT, literacy and & $67 \%$ \\
Developed critical thinking skills & $67 \%$ \\
Helped students make connections to real world situations & $75 \%$ \\
Built and maintained heightened interest & $83 \%$ \\
Fostered more interaction & $67 \%$ \\
Use multiple intelligence & $62 \%$ \\
\hline
\end{tabular}

\section{Discussion}

Conducting professional development training with PTs to facilitate implementation of the new integrated, thematic curriculum while on practice, positively impacted their level of performance. Adequate support empowered them to meet better the needs of the students that they taught. The majority of prospective teachers in the study felt that the thematic, integrated curriculum offered them the flexibility to cover more content. With the integrated approach, they were better able to meet the needs of the students during their field teaching practice while conducting their thematic, integrated sessions in reading, math, social studies, and science. PTs felt that they met the needs of students by helping students develop key skills across disciplines.(John \& Joseph, 2014).

The majority of prospective teachers felt that the thematic, integrated curriculum empowered them to integrate all subjects and use literacy and numeracy across the curriculum. They helped their students understand and make connections. The lessons they prepared and executed helped prospective teachers to focus their teaching and learning on mastery of the goals and objectives set out at the beginning of their lessons.

Using the new curriculum encouraged them to differentiate instruction and students experienced many different ways of learning. Implementation of the new curriculum increased engagement through many learning activities. Prospective teachers felt that their students had a topic choice.

Prospective teachers felt that the new curriculum approach allowed them to integrate technology into their lessons. They were able to compact the curriculum to reach the gifted students and to assist the students who needed assistive technology to level the playing field.

The thematically integrated approach allowed prospective teachers to utilize the collaborative and cooperative learning, enabling them to share the same learning goals, creating a community of learners. Most prospective teachers enjoyed engaging the students in strategies such as shared reading lessons. During whole group instruction, shared reading blended with the new thematic, integrative curriculum (John \& Joseph, 2015). PT reported that it was easy to conduct activities for multiple stations. PTs designed the class activities so that their expectations were communicated and articulated to the children. During shared reading, most prospective teachers conducted their instruction with creativity, while others conducted it using a more structured approach. (John \& Joseph, 2015). Prospective teachers perceived that use of thematic, integrative approach made learning enjoyable, and it totally engaged their students. Most of the PTs claimed that they provided their students with the opportunities to participate actively.

\subsection{Benefits and Impact}

Prospective teachers perceived benefits and advantages of thematic, integrative curriculum. They also felt that the curriculum impacted teaching and learning. Across the twenty schools, prospective teachers' responses triangulated with the quantitative analysis and hence signified that use of the integrated thematic curriculum had innumerable advantages for students. The benefits to prospective teachers were that a thematic, integrated curriculum made it easier to plan units from the curriculum. They were able to cover more content and help students make connections to everyday life. 
Prospective teachers assigned to Infant One used the thematic units from "Me and My World" to engage students in the learning process with a variety of lessons and projects. PT used a balanced literacy approach and integrated subjects (VAPA, Science, Spanish, Agriculture Science and Social Studies). The common theme kept student learning focused on the broad concept while touching on specific knowledge and skills throughout. PTs mention that thematically integrative units provide one of the best means of integrating content areas in a way that is relevant to children. It helps them make connections to transfer the knowledge they learn and apply it in a meaningful way.

As far as the pupils were concerned, prospective teachers felt that offering opportunities for contextualized learning meant that it made sense and was more relevant and practical. They thought that the pupils found learning both fun and enjoyable. They also considered that by delivering the curriculum thematically, a variety of learning styles was addressed. (www.gillmatthews.co.uk., n.d.).

Prospective teachers when asked about the effectiveness of their teaching using the new thematic integrative curriculum; most focused on the influence that the new curriculum had on the pupils' learning than on their teaching. However, the majority of prospective teachers felt that their teaching was more creative and focused. PT felt that training using the new curriculum empowered them to work within the curriculum frameworks and to capture the MOE focus for primary school educators. It helped them to demonstrate their content knowledge, and it enabled them to be more creative with the curriculum.

The most common comment about the impact on learning was that students were more engaged and motivated. PTs perceived that a lot more learning took place. PTs commented on the improvement in independent learning. They saw evidence of this both in the classroom, with children taking more responsibility for their learning, and at home, with children completing homework assignments, as an extension of class work. PTs noted that content standards, particularly in terms of reading improved. PTs conducted pre-testing prior to starting their practicum and post-testing on completion of the practicum, in reading. In all twenty schools, students' reading level improved over the six-week period. Students who were given one-one interventions during the period moved up at least one-grade equivalence level, on average. Some prospective teachers stated in their reflections that students' behavior improved, as did their attitude towards learning.

\subsection{Implications for Implementation}

There exist resistance to the new curriculum in the majority of schools in Trinidad and Tobago. Implementing the new curriculum takes time and much practice. It also means a change in mindset, from the traditional mode of a more interactive approach. MOETT states that it is a paradigm shift. Indeed it is. For successful implementation to occur, teachers in Trinidad and Tobago must adjust their belief system from one that is didactic in nature to one that has a foundation in constructivism. Rather than asking students to follow steps of the procedure, memorize facts, or verify given principles or laws, students must work together to discover knowledge, applying their knowledge as they solve real-world problems.

Teacher/school resistance to the new curriculum has implications for teaching and learning outcomes in Trinidad and Tobago. The inability of the majority of Trinidad and Tobago teachers/schools to make education more relevant and fun while building transferable life skills inhibit students' performance. Research conducted in schools that follow thematic, integrative approach to curriculum raised their average test scores two and a half levels in math and one and a half levels in reading. (What is Curriculum? -ASCD, n.d.). A study of 15 micro-society schools in six states of the United States of America, found that at two-thirds of the schools, students posted gains on standardized reading and math tests, that were as much as 21 percent greater than those of their peers (ASCD, n.d.). In three examples cited in that study, student achievement was the primary focus. Teachers maintain accountability while designing learning experiences that are relevant to student interests. Two of the schools served populations of diverse students. In each case, teachers have developed an intriguing curriculum that pushes beyond the boundaries of traditional disciplines to produce positive results. In these micro-society - Best schools, comprehension, is comprehension, whether taught in a language class or a science class. When students become engaged in learning, whether they are taking part in the arts or role playing in a micro-society, they do well in seemingly unconnected academic arenas. (ASCD, n.d.)

Successful implementation means that teachers engage in an extensive amount of professional development. Professional development should include a significant intervention of two or three weeks of knowledge development in curriculum areas other than the one they used over the last decade. According to JOTS, (n.d.), this professional development must include extensive practice in the use of constructivist-oriented pedagogy. 
Teachers need to become members of learning communities, working with a team, to improve education. They also need to get skilled in facilitating differentiated instruction, by using relevant assessment tools that help in the formulation of small group learning at the instructional level. Research has shown that learning is a social process and that students learn a great deal by interacting with one another. (JOTS, n.d.).

Teachers need to manage experiential-oriented instruction. That is they should include inventorying and storing materials; the safe operation of instrumentation, machines, and equipment; and leading students toward efficient progress. (JOTS, n.d.).

\subsection{Next steps}

In the light of this research project, there are many points that the schools and the Ministry of Education of Trinidad and Tobago can now consider.

1. More professional development in the use of the new thematic, integrated curriculum is needed. Resistance to the curriculum is a product of lack of explicit training and the perception that the new curriculum will increase the level of work that teachers must do to be effective. Training should not be just surface deep, but should be more systematic, explicit and interactive. Also, all stakeholders should be a part of the training, the principals, senior teachers, grade teams and parents. There is a need for greater bye-in.

2. Provision of adequate resources, both inside and outside the school. Teachers and administrators will be encouraged to broaden children's experiences and include key events in themes if resources are available. Visits and experiences need to have a particular focus and purpose. They do not always have to happen at the end of a theme like a reward, but sometimes as an initial experience to kick-start the theme and to stimulate the children's interest. These experiences do not always need to involve the children going out of school, or indeed inviting a visitor into school. If experiences are an important part of the thematic, integrative curriculum, then classroom environment should be considered.

3. Teachers need to learn to use authentic assessment strategies such as portfolios, performance exams, and rubrics to document student progress. (JOTS, n.d.)

4. Administrators and curriculum supervisors and school supervisors need orientation as well, so the necessary resources and ongoing support can be provided to the teachers. During 2014, MOE Heads of Department Training, most administrators, and senior teachers had no clue of the content of the new curriculum. They reported that they were not a part of the initial training process for the new thematic, integrated curriculum.

5. Of equal importance is public information strategies need to be implemented that informs the community and parents that a new paradigm of education is being used. The expectation is for education to be provided as it has always been, and unless the public is informed of these changes to be made, there is likely to be resistance. (JOTS, n.d.). Lastly, changing to an integrated thematic curriculum requires systemic reform. Reform that includes the way teachers are prepared, certified, and assessed. Attention must also be given to national assessment of students. (JOTS, n.d.)

\section{Limitations}

\subsection{Access to the students}

The short time spent during Field Teaching practice, as well as, the timing of the study limited the results of the study. Prospective teachers were in the field from January 2014 to March 2014. This school term is plagued by numerous external, distracting events, namely Carnival in Trinidad and Tobago. Additionally, some cooperating teachers resisted the implementation of the new curriculum. Therefore, prospective teachers had the task of convincing directing teachers that the new curriculum was more enabling than the old and that once embraced, the advantages far outstripped their fears.

There were some issues with adjusting the learning environment to suit the teaching of differentiated lessons, especially in small, crowded classrooms. While PTs in the experiment group were effective in the diagnosis and prescription of reading needs, and in matching instruction to needs, they perceived that they needed more practice in managing the rest of the class during Guided Reading.

\section{Future Research}

Based on the results of this study, further experimental research will be conducted with emphasis on classroom management of groups while the teacher gives instruction to small groups. Further research that will focus on the 
organization, behavior management and development of engaging activities for students at the independent stations will empower prospective teachers.

Future research should be done measuring the impact of differentiated instruction using the new thematic, integrated curriculum in schools currently using the curriculum vs. schools that are not. Several national tests can show if the utilization of the new curriculum.

\section{References}

21st Century Learning: Making Technology Relevant in Today's ... (n.d.). Retrieved from $\mathrm{http} / /$ thejournal.com/articles/2008/05/21/21st-century-learning-making-technology-relevant-in-todays-classroo ms.aspx.

Bandura, A. (1989). Social cognitive theory. In R. Vasta (Ed.), Annals of Child Development (Vol. 6, pp.

Curriculum - Ministry of Education. (n.d.). Retrieved from http://www.moe.edu.tt/learning/primary/curriculum.

Curriculum Integration in Medical Education: A Theoretical ... (n.d.). Retrieved from http://www.esciencecentral.org/journals/curriculum-integration-in-medical-education-a-theoretical-review-ipr.1 000113.php?aid=25085

Fogarty, R. (1991). Ten ways to integrate curriculum. Educational Leadership. 49(2), pp61-65.

Fogarty, R. \& Stoehr, J.(1995). Integrating curricula with multiple intelligences teams, themes, and threads. Illinois: IRI/SkyLight.

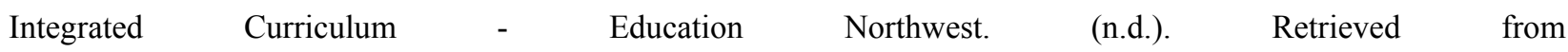
http://educationnorthwest.org/sites/default/files/integrated-curriculum.pdf

Integrated Curriculum by Kathy Lake Introduction. (n.d.). Retrieved from http://www.bfincher.net/sixth/hum_background/language/Integrated_Curriculum.pdf

Integrating the Curriculum | Society and Environment. (n.d.). Retrieved from https://taylorcara.wordpress.c/2014/03/27/integrating-the-curriculum/

Integration of the Disciplines - Fragmented. (n.d.). Retrieved from http://oregonstate.edu/instruction/ed555/zone3/single1.htm

John, Y.J. \& Joseph, S. (2015). Differentiated Instruction Training for Prospective Teachers: An approach to Improving Reading in the Primary Classroom. Literacy and (LICEJ).

John, Y. J., Joseph, S., Sampson, A. (2014). Prospective teachers using guided math to differentiate mathematics instruction - International Journal of Research In Social Sciences (IJRSS). Vol(4)1. IJSK.org

JOTS v25n2 - Models of Curriculum Integration. (n.d.). Retrieved from http://scholar.lib.vt.edu/ejournals/JOTS/Summer-Fall-1999/Loepp.html

Kauchak, D., \& Eggen, P. (2005). Introduction to teaching: Becoming a professional. Upper Saddle River, NJ: Pearson Education, Inc.

Ministry of Education of the Republic of Trinidad and Tobago (MOETT), (February, 2014). Primary School Curriculum Teacher's Guide. $\quad$ Retrieved http://www.moe.edu.tt/learning/primary/curriculum/item/267-primary-curriculum-guides-sept-2013.

Primary Curriculum Guides (FEB 2014) - Ministry of Education. (n.d.). Retrieved from http://moe.edu.tt/learning/primary/curriculum/item/267-primary-curriculum-guides.

Shanker, J. (2014) $6^{\text {th }}$ Edition. Eckwall/Shanker Reading Inventory. ISBN13: 978-0132849968, ISBN10: 0132849968: Allyn \& Bacon, Inc.

Thematic Instruction | Teaching Methods | Funderstanding ... (n.d.). Retrieved from http://www.funderstanding.com/educators/thematic-instruction/What Is Integrated Curriculum? - ASCD. (n.d.). Retrieved

from http://www.ascd.org/publications/books/103011/chapters/What-Is-Integrated-Curriculum\%C2\%A2.aspx

Unit Plan Format 1. Unit Author(s)/First and Last Name. (n.d.). Retrieved from http://www.bloomu.edu/documents/coe/UnitPlanScoringGuide.pdf.

What Is Integrated Curriculum? - $A S C D$ (n.d.). Retrieved from http://www.ascd.org/publications/books/103011/chapters/What-Is-Integrated-Curriculum\%C2\%A2.aspx

$\begin{array}{lll}\text { www.gillmatthews.co.uk. } & \text { (n.d.). } & \text { Retrieved }\end{array}$ http://www.gillmatthews.co.uk/images/articles/thematic_curriculum_research_article.doc. 